\title{
Revisiting the Concept of Debordering: The Case of the Slovenian-Hungarian Border Region
}

Received: June 13, $2020 \bullet$ Accepted: June 23, 2020

Tatiana Bajuk Senčar

ZRC SAZU Institute of Slovenian Ethnology, Ljubljana

\begin{abstract}
The following essay examines the concept and practice of debordering as an element of EU integration with the aid of ethnographic research on local actors' experiences with EU cross-border programs in the Slovenian-Hungarian border region. The analysis is based on defining and distinguishing among the historical, normative, and analytical dimensions of debordering, focusing on critical analyses of its uses as an analytical concept. The author proposes a more grounded approach to debordering by contextualizing interlocutors' narrated border experiences in a broader analytical and interpretative framework.
\end{abstract}

Keywords: border regions, Slovenia, Hungary, debordering, European Union, Europeanization

\section{INTRODUCTION}

From late 2019 onwards, the world has been engulfed in a global health crisis. The COVID-19 pandemic resulted in the simultaneous lockdown of approximately one half of the world's population in early April 2020 (SANDFORD 2020). This generalized lockdown also extended to the European Union, whose vision of a "borderless Europe" facilitated the unimpeded flows of persons, services, capital, and goods until a few months ago. The world watched as one EU country after another closed its national borders (sometimes even regions and municipal ones), fortifying previously deserted checkpoints. This was also the case for the border between Slovenia and Hungary. Once part of the Iron Curtain, this border was closed on 13 March of this year, with border police erecting concrete barriers to prevent the previously normal flow of border traffic except at a limited number of border crossings (HANžıč 2020). The border regime has been modified many times - and then relaxed - over the following weeks and months, as states coordinated on a bilateral level to deal with issues arising from changes to border regimes - a scenario that played out across Europe and beyond. In all cases, decisions taken in national capitals were implemented within hours, demonstrating the extent of national governments' power over the entirety of their territories.

The shifting border regimes across Europe - which can be defined as rebordering measures - were quite striking given the decades-long integration project set in motion 
by the European Union. EU integration resulted in a certain degree of institutional and geographic reterritorialization as well as of debordering - a physical indicator of which include the disappearing borders (GIRTLER 1992; DONNAN - HALLER 2000) within the Schengen zone. ${ }^{1}$

What do these recent events mean for the debordering processes that have been one of the hallmarks of EU integration shaping the region in the last decades? Observing the recent responses on the part of EU member states to the global pandemic - particularly in the face of the relative inaction of the EU - compels one to question the role of integration that has been the raison d'etre of the EU from its very inception. It was initially founded as the European Coal and Steel Community (ECSC) in 1951 to form a common market for coal and steel. This community aimed to diminish competition for the natural resources needed to make munitions, which, according to Robert Schuman, one of the EU's founding fathers, was meant to render war "not merely unthinkable, but materially impossible" (SCHUMAN 1950). Since then, the EU has continued to evolve and expand, employing diverse mechanisms to promote new forms of interdependence and cooperation - not only among its member states but also with numerous countries and regions outside it.

The following essay examines the concept and practice of debordering as an element of EU integration with the aid of ethnographic research focusing on experiences with EU cross-border funding conducted in the Slovenian-Hungarian border region. ${ }^{2}$ The discussion is based on mapping out the historical, normative, and analytical dimensions of debordering, building upon the distinction between the analytic and normative dimensions of integration discourse drawn by Abdelmalek Sayad (SAYAD 2004). Numerous researchers have discussed the normative dimension of EU integration as a concept and a project (including MCDonald 1997; Holmes 2000; SHORE 2000; AbÉLÈs 2004; BAJUK SENČAR 2014). In much the same vein, the notion of debordering - understood most broadly as the loosening or dismantling of border regimes - does not operate solely as a descriptive or analytic concept. It also has a strong normative dimension, particularly within the framework or EU discourse. This normativity can manifest itself, for example, in the framing of cross-border cooperation and interdependence as well as the opening of national borders as self-evident processes leading to a presupposed end that is framed in at least neutral, if not positive, terms (ABÉLÈs 2000).

The ethnographic examination builds on a brief portrayal of the role of borders in the evolution of the EU and the way that border scholars have analyzed and critically engaged debordering as a political and social process. These discussions will then provide the analytical framework for the ethnographic case study conducted in the SlovenianHungarian border region.

1 As many have pointed out, integration processes across Europe are primarily, but not only, due to the evolution and expansion of the European Union (BORNEMAN - FowLER 1997). Thus, when referring to reterritorialization or integration processes more broadly, I employ "Europeanization" instead of "EU integration".

2 This article is based on research conducted within the scope of the ongoing bilateral research project Protected areas along the Slovenian-Hungarian Border: Challenges of Cooperation and Sustainable Development (J6-8254) and the research program Cultural Spaces and Practices: Ethnology and Folklore Studies (P6-088), both funded by the Slovenian Research Agency. 


\section{BORDERS AND BORDER REGIONS IN THE EUROPEAN UNION}

As the EU evolved and expanded, borders and border regions became a stronger priority. The first cross-border initiatives began to develop as early as the 1960s and first took the form of European border regions established by regional and local actors from both sides of a particular national border. According to Alfred Mozer, one of the main supporters of the first European border region along the German-Dutch border, cooperation that transcended boundaries was meant to "overcome national frontiers in order to heal the scars of history" (MOzER 1973). Making connections across frontiers was meant to reframe relationships marked by differences as well as historical tensions. Mozer also became the first president of the Association of European Border Regions (ABER), which was composed of border and cross-border regions. The association saw crossborder cooperation as a way to resolve the everyday problems that border populations experienced and improve relations with neighboring countries (ReITEL et al. 2015).

These first cross-border initiatives, which took the form of cross-border regions, did not necessarily develop within the EU institutional framework but in connection with it. Only after the EU reformed its regional policy in 1988 did it begin to consider cross-border cooperation as a priority, which resulted in the establishment of the Interreg program in 1990. Its purpose was to promote connections across national borders and the development of cross-border regions - albeit from within a multi-lateral, EU context. ${ }^{3}$ Cooperation across borders was considered to be evidence of European unity, and it provided benefits in terms of economic growth and territorial cohesion (KAISER et al. 2009). The EU also paid particular attention to the border regions of its accession states, including Slovenia and Hungary, who were eligible for support from special programs (e.g., the Phare program). ${ }^{4}$

Looking back over the postwar period, it becomes apparent that there were two traditions of cross-border cooperation (O'Dowd 2002). The first, centered on European border regions that developed in an environment of post-war reconciliation, aimed to offer pragmatic solutions to specific border challenges through local, regional, and national cross-border collaboration conducted primarily in a bilateral context. The second tradition, largely incorporated into the first by the 1990s, was built on the concept of EU integration as an ever-closer union (free flow of goods, services, capital, and people) and hinged on a supranational, i.e., multilateral operation.

In the latter tradition, cross-border regions became seen as models or laboratories for European integration, given their daily practices of cross-border mobility and constant interactions with their neighboring countries (REITEL et al. 2015:14). Characterizing crossborder regions as model areas or laboratories indicates that cross-border cooperation was incorporated into the normative discourses linked to EU integration as a political process - portraying what Europe could be and how it should evolve.

3 Interreg has evolved since its inception in 1990 to cover all 28 EU member states, three participating EFTA countries (Norway, Switzerland, Liechtenstein), six accession countries, and eighteen neighboring countries. Its programs now promote three different scales of cooperation: crossborder, transnational, and inter-regional cooperation. See https://interreg.eu for more on the Interreg program.

4 Please see https://www.europarl.europa.eu/enlargement/briefings/33a2_en.htm for basic information about the Phare program's role in the EU accession process. (accessed January 12, 2021) 


\section{DEBORDERING AS AN ANALYTICAL CONCEPT AND OBJECT OF RESEARCH}

The expansion and impact of the EU beyond its frontiers have inspired significant scientific and academic interest, including among border scholars. Border specialist Thomas M. Wilson describes the EU as "perhaps the greatest experiment in postnational and supranational polity building in the world today" (WILSON 2012:169) - an experiment that strongly informs national border regimes throughout Europe and beyond. Yet given the broad range of theories, methods, and approaches that characterize border studies, the lack of a common definition for or approach to debordering comes as no surprise. Despite this, it is possible to map out significant distinctions among existing lines of inquiry linked to debordering in the European context.

At the broadest level, debordering is considered to be a distinctive feature of European integration. In this context, it is primarily understood in its most formal sense, as a top-down opening of borders or diminishing their role as barriers (O'DowD 2002). This sort of understanding often operates as a tacit, taken-for-granted frame of reference that serves as a starting point of analysis. It is often referred to as a fait accompli, set in contrast to the operation of national borders that is the norm outside supranational formations.

This "common denominator" conceptualization of debordering is more structural than dynamic (VAN Houtum et al. 2016) and refers primarily to changing border regimes or features. However, another definition moves beyond this more static approach to focus on bordering practices understood more broadly - practices and processes facilitated by open borders. These are depicted as points of contact that can facilitate the possible formation of ties, networks, and practices, which can reconfigure relationships between border groups and communities (SCOTT 2012; SoHN 2014).

The diverse definitions of debordering as a process - an exhaustive discussion of which transcends the boundaries of this essay - is contingent on particular understandings of borders as well as disciplinary priorities and methods. Many analysts examine debordering within the context of EU cross-border cooperation or integration, be it concerning European cross-border regions or EU programs stimulating cross-border cooperation. For example, some focus on cross-border cooperation through the lens of the development of new (non-national) forms of governance or territorial configuration (including POPESCU 2008) within cross-border regions, highlighting the links between border governance, territoriality, and spatiality. Others focus on identifying or analyzing the different factors that can affect how local and regional actors view open borders, which can operate as potential resources and engines for integration or cooperation (e.g., SoHN 2014). Finally, others employ a broader focus and link debordering to established discussions on global flows of information, capital, media, and culture. They address an additional set of issues, including supranational notions of citizenship and identity, thus also addressing borders as markers of identity (MCCALL 2012).

While normative depictions of EU integration are "uni-directional", moving towards an ever-present union and a higher level of debordering, EU studies specialists have called attention to the fact that the $\mathrm{EU}$ is also the site of an extensive range of rebordering practices. For some, this is framed in terms of a lack of success or adverse reaction to EU debordering initiative or programs: be it that a specific cross-border program has not 
necessarily flourished or a particular region has not quite succeeded in coming together across borders (VAN HouTum et al. 2016). Another rebordering trend that has been the subject of considerable analytical attention is the reversion of specific border regime changes, including, for example, the reinstatement of individual border controls in the face of a perceived crisis (MCCALL 2012).

It is not difficult to ascertain a lack of distance from the normative dimension of EU integration discourse in those analyses that discuss rebordering primarily as a reversion or problem. However, most studies that fall into this category view rebordering as a particular form of border practice taking place in the face of EU integration as an ongoing, openended process (CASSIDY et al. 2018). Nevertheless, some researchers explicitly and critically engage the EU project, arguing that debordering and rebordering processes are at the center of EU integration. Some take issue with the notion of a borderless Europe, pointing out how opening borders can also result in creating new boundaries or strengthening existing ones - including regional borders (e.g., WILSON 2012). Others call attention to the marked difference between the EU's internal and external borders, even those with other European countries. Rebordering in this context informs the dynamic of broader Europeanization processes, contributing an additional dimension to the Fortress Europe concept often invoked when referring to the impermeability of Europe's external borders (e.g., MANDEL 1994; Del Sarto 2010; Follis 2012). Another significant argument questions the idea of the EU being a homogeneous, borderless entity, arguing instead that it is composed of multiple supranational spaces. Some spaces are meant to espouse particular border regimes, others delimit certain forms of economic cooperation, and yet others serve as markers of collective identity. As a result, it becomes challenging to accurately map out Europe's "relative location" across time and space, as Sarah Green argues:

\footnotetext{
"the question of where the borders of Europe may be located is not a simple matter of locating the boundaries, the edges, of somewhere; rather it requires an understanding of both past and current relations among places (which could be called 'relative location'); an understanding of the classification system used to establish what used to be included and excluded; and an understanding of other regional practices that either reinforce or challenge the EU's formal intended relationships among its various bits and pieces" (GreEN 2013:348).
}

Green argues for locating Europe in a broad relational context, including a spatially defined history of its relationships with other places, which in turn could serve as a frame of reference for research on any given European border practices. Such an approach addresses the question of Europe's specific contingency and helps identify the questions needed to broaden existing research approaches. In a similar vein, one can also argue for the identification and foregrounding of questions and issues that can help fashion a more grounded approach to the study of debordering within an appropriate frame of reference.

\section{CONTEXTUALIZING DEBORDERING PRACTICES IN THE SLOVENIAN-HUNGARIAN BORDERLANDS}

The borderlands between Hungary and Slovenia have undergone tremendous change during the last century. After the fall of the Iron Curtain, the expansion of the EU in 
2004 and the Schengen Area in 2007 resulted in a virtually borderless region between both countries. Within the context of a Hungarian-Slovenian research project carried out in the border region (FIKFAK - MÉSZÁros 2019), I researched EU funding initiatives specifically EU cross-border programs meant to encourage debordering. Working from the argument that border practices in the EU are multiply defined and not only the domain of the state or a supranational political body (RUMFORD 2006), my focus was on local and regional actors participating in EU projects along the Slovenian-Hungarian border. I set out to explore the perspectives of social actors who participated in projects or experienced them on an everyday level. I carried out ethnographic interviews in the northwestern portion of the border region (primarily in the Slovenian Goričko region), complemented by archival research and media analysis. My interviewees included members of municipal governments, tourism organizations, state agencies, park administrations, regional cultural institutions, and regional development agencies (BAJUK SENČAR 2019). ${ }^{5}$

The EU has been promoting cross-border cooperation in the Hungarian-Slovenian borderlands from the mid-1990s onwards, when both countries were eligible for financial support as accession countries through the Phare program. While the Phare program's primary objectives were to support institution-building and the convergence between national and EU legislation, it also had a cross-border component. Slovenia and Hungary formed part of a trilateral Phare cross-border program (Austria, Hungary, and Slovenia), followed by a bilateral program. One of the more significant projects from this period was the creation of a trilateral regional park that combined Raab Nature Park (Austria), Örség National Park (Hungary), and Goričko Nature Park (Slovenia). The park was created to coordinate nature preservation and sustainable development in the border region between Austria, Slovenia, and Hungary (DEŠNIK - DoMANJKo 2011).

The aforementioned Interreg program, which presently funds cross-border participation between Slovenia and Hungary, aims to stimulate cooperation between regions as well as facilitate balanced social and economic development. Cooperation between Slovenia and Hungary in the Interreg program began with the trilateral Neighborhood Program (Hungary, Slovenia, and Croatia), which took place from 2004 through 2006. This served as the foundation for developing a bilateral cross-border program between Hungary and Slovenia, which ran for two programming periods - 2007-2013 and 20142020 - with preparations underway for the following programming period starting in $2021 .^{6}$ The strategic objectives of both programs involved improving conditions and opportunities for sustainable development in the region in order to maintain as well as attract inhabitants to the area.

The analysis of interviews with persons who participated in cross-border projects in the border region centers on exploring specific questions. What were the coordinates of their talks about the EU and cross-border initiatives? How and where did they situate these projects - not only in spatial terms but also in terms of existing and emerging relationships and networks? These questions were meant to help identify the position and

\footnotetext{
5 Interviews cited in this article were conducted during January and February 2019 and March 2019. I conducted many of the interviews in March 2019 with project colleague Dr. Marjeta Pisk. All interviews are anonymous and were conducted in Slovene.

6 For more on the Slovenian-Hungarian Interreg Programs see: Služba Vlade RS za RazvoJ IN EVROPSKO KOHEZIJSKO POLITIKO 2015.
} 
views of those actors, institutions, and groups who help shape the region's specific groundlevel border dynamics and processes - beyond the frame of reference concerning crossborder cooperation as defined by regional, national, and EU authorities. Furthermore, they aid in exploring how varied understandings and expressions of peripherality shape experiences with cross-border projects. Such an approach helps position actors and their experiences vis à vis those authorities and institutions that operate from the top down and from national or supranational centers (BAJUK SENČAR 2019). Furthermore, it can serve as a forum for situating interlocutors' narrated experiences with debordering projects in a broader analytical and interpretative framework.

Recent studies along the Slovenian-Hungarian border have raised significant issues that help guide the contextualization of debordering questions and processes. One such issue is the complex history of the border region, including its narrated presence in the collective memory of border communities (MUNDA HIRNÖK - SLAVEC GRADIŠNIK 2019), the transformation of border communities over time (SIMONIČ 2019), and the introduction of new forms of nature conservation, which can also result in the creation of new boundaries (IsPÁN 2019). These lines of inquiry help flesh out the specific circumstances of this particular border and its forms of border practice. Others have foregrounded the significance of wildlife's cross-border activities and its impact on bordering dynamics in local communities (Kozorog 2019). Studies in this vein demonstrate the importance of incorporating the existing range of debordering actors to adequately frame the experiences and practices in any given border region. Furthermore, other research on EU projects in the border region demonstrates how the implementation of such projects involves not only national borders but also a range of other boundaries - whether they are inscribed into the natural landscape or structure social life in local communities (MÉszéros 2019).

Examining how the implementation of debordering programs involves other actors and boundaries can offer essential insights into the impact of projects in a particular region. In addition, analysis of EU debordering projects and initiatives intended to encourage cooperation can highlight tensions or even cause disruptions along boundaries, pointing out how debordering and rebordering processes can often operate as two sides of the same coin. In the final section of this case study, I examine the relationship between debordering and rebordering through interlocutors' experiences of EU projects by identifying their significant expressions of bordering practice. In this context, the notion of bordering encompasses all the practices, processes, and relationships that contribute to a sense of border - or "borderness" - both in spatial and social terms (GREEN 2012). Understanding the role of EU projects hinges on embedding them within the interlocutors' existing referential framework of relevant relationships and boundaries in terms of which they experience "borderness", keeping in mind that a sense of border can be multiply defined. This implies broadening the analytical focus beyond the spatial international border to include relevant boundaries and distinctions (spatial, economic, ethnic, and historical) that can either help generate borders or transcend them. Thus, in the following pages, I will discuss a selection of boundaries and borders most often mentioned in interviews as essential to "borderness" experiences - as well as the debordering and rebordering practices that EU projects set in motion. What sorts of borders and boundaries structure their narratives, and why do interlocutors invoke them when talking about EU projects? The case study discussion concludes with a focus on select boundaries that seemed most significant to interlocutors when narrating their experiences with EU projects. 


\section{The boundary between center and periphery}

The boundary between the center (the state) and border as a periphery was an important theme, often invoked in conversations about EU projects. This boundary is not a border in the traditional sense of the term but is the result of a relationship defined by a sense of marked difference, which is expressed spatially, yet not articulated in terms of a single geographical line. One cannot pinpoint where the center ends and the periphery begins; furthermore, this is not a point of contestation or contention in the face of diverse or even divergent opinions or views. Instead, the boundary serves to characterize a relationship considered to be - from the perspective of the periphery - unequal, or, at best, ambivalent. It is often framed negatively in terms of distance or a lack of status that manifests itself in numerous ways - politically, economically, and socially. Furthermore, while this discussion is focused on the center-periphery relationship between a national center and a border region, peripherality can be attributed in degrees, with certain regions or places depicted as more "peripheral" than others.

Conversations concerning EU projects often invoke the center-periphery distinction instead of the national border - particularly when discussing motivations behind seeking EU-based funding. People apply for projects in the hopes of compensating for lack of funding, as is apparent from the following interlocutor, whose motivations for EU projects are linked directly with his institution's regional (peripheral) status: "The state does not offer any funds for investments to help carry out our work (computers, cameras, software, hardware, archival work, digitalization). Without the aid of EU projects, we could not afford to purchase what has become a necessity for the production of quality work in this day and age." " Thus, in some cases, EU projects are described as mechanisms for attaining financial autonomy from the national center. However, this autonomy can also be defined spatially in terms of mobility and infrastructure. For example, an official from a regional development agency described project plans to connect regional transportation networks across borders to offer sustainable mobility options for residents and businesses. The plan was to cooperate with the neighboring border regions to improve regional mobility and capitalize on their positioning - independently of the state center: "The idea is to prepare mobility strategies for the entire region - as a region at the crossroads - but we know that we need the neighboring regions for such a plan, not only the Slovenian region but also the Hungarian and the Austrian ones."

While some project ideas are based on imagining an interconnected set of border regions, others sometimes seem to heighten tensions between state and periphery, particularly in cross-border project management. For example, a significant degree of decision-making and management of cross-border programs is delegated to member states; this implies that the state becomes an integral element of EU cross-border programs. ${ }^{9}$ Many interlocutors express strong opinions concerning the role of the state in managing and reviewing project implementation, which was not viewed very favorably: "It is much easier to work with Brussels; they do not complicate things as much. The

\footnotetext{
7 Interview with an employee in a regional cultural institution (March 2019).

8 Interview with a regional development agency official (March 2019).

9 Interview with a Slovenian civil servant (January 2018).
} 
worst is when the ones from the National Budget Supervision Office come to see you."10 The state's role as the supervisor of cross-border projects can thus be seen as a new dimension of the relationship between center and periphery, which can cause tension and heighten existing boundaries.

\section{Boundaries between national project stakeholders}

The support that EU cross-border programs can provide serves as the basis for a range of interactions among potentially eligible border actors or stakeholders - interactions that may result in the forging of ties or the drawing of boundaries. On the one hand, one can observe strategic networking at the local/municipal and regional levels, as different stakeholders work together in varying combinations to increase their chances of securing financial support. Setting up appropriate partnerships is seen as a condition for success - based on compliance with project stipulations and informal guidelines gained through experience. As a result, experienced institutions begin to develop networks of potential partners for their EU project ideas. These networks, often based on previous project collaborations, are composed of a variety of institutions - including municipalities, nature parks, development agencies, tourism organizations, and other local/regional institutions: "In all these years, you form a network of partners to work with that you trust. Sometimes new partners come into the picture, but if things do not work out, you do not invite them next time."11

On the other hand, the existence of networks does not imply a lack of competition or diverse strategies, priorities, and interests. As is implied in the excerpt cited above, project-based interactions offer partners the opportunity to identify the institutions they work well with and those with which they do not. The decision to not work with a particular institution can be due to numerous factors: from incompatible styles of operation to differing project priorities to divergent motivations for securing EU funding. Some consider this diversity - and the consequent competition for EU funding - to be detrimental to the level of cooperation among border institutions: "Sometimes we wind up working only for ourselves, parallel with one another, not knowing what the other is already doing. The only important thing is that we get the project for the next three years." 12 Another significant issue is linked to a perceived incompatibility concerning motivations for seeking monetary support, which in turn operates as a source of tension among border region actors or stakeholders. For some, EU funding provides an opportunity to finance ideas beneficial for local development, with EU programs serving to realize local interests insofar as project partners can successfully frame a project idea in terms of the express priorities of EU funding calls. These local interests can sometimes even be reduced to a given institution's continued existence. On the other end of the spectrum, one can find institutions that have acquired considerable experience and expertise in securing EU projects, which in turn becomes the institution's raison d'être: to obtain enough EU funding to finance itself. In this regard, EU programs are reduced

\footnotetext{
10 Interview with a municipal official (March 2019).

11 Interview with a representative of a municipal tourism organization (March 2019).

12 Interview with a representative of a development agency (February 2018).
} 
to helping maintain a niche institution that develops project ideas aimed at effectively responding to the EU's changing priorities. The competition between differing project initiatives can, in some cases, seem to foreground rival personal motivations as opposed to differing priorities for the region.

\section{The boundary between the Slovenian and Hungarian border regions}

Cooperation on joint projects offers participants the opportunity to gain experience and knowledge about their cross-border partners as well as compare and contrast circumstances on either side of the border: "EU projects are important because they open your eyes. These exchanges are crucial because you are faced with different ways of thinking. The best thing is that people begin to look across the border and talk to each other." ${ }^{13}$ These exchanges can heighten a sense of difference, a sense of connection, or encourage joint solutions to common problems.

Many interlocutors mentioned the language barrier as a challenge that still exists despite the open border regime. While there are numerous bilingual border actors, the linguistic border continues to function as a "hard" boundary for many of those who work in cross-border projects, hindering effective communication. Several solutions for this problem came up in discussions. Speaking a third, common language was often mentioned for more informal interactions, while using interpreters and translators was an established practice for more formal meetings. Engaging the services of bilingual border actors also came up as a useful strategy, providing them with the opportunity to work as language brokers as well as project partners.

Interactions with cross-border partners also highlighted the fact that the (open) international border marked a boundary between two states and, consequently, distinct state bureaucracies (MINNICH 2006) - a distinction that can become apparent in crossborder cooperation. For example, Slovene interlocutors often mentioned the differing roles of the Hungarian and Slovenian states concerning the financial support of EU projects. In recent years, the EU has lowered the percentage of budget funding of approved project budgets to $85 \%$, with applicants being required to provide proof of funding for the remaining $15 \%$. This condition is challenging for many smaller organizations, businesses, and even municipalities in Slovenia, who mentioned the financial support that the Hungarian state provided for approved projects to cover budget costs. This difference manifests itself as a perceived asymmetry and a potential obstacle to identifying common, feasible project priorities across borders.

Nevertheless, cross-border projects were also described as platforms for connection that could help partners realize shared goals. One such goal is the development of local, sustainable tourism, which interlocutors on both sides of the border mentioned as a strategic interest that can offer a viable livelihood for residents. They looked to sustainable cross-border tourism to increase visitors and link together tourism service providers - locally as well as across the border. A Slovenian municipal official describes an ongoing cross-border tourism project in the following words: "We are trying to link

13 Interview with an official from a local tourist organization (March 2019). 
together tourism service providers from the Slovenian side and the Hungarian side to create a network, attract tourists to the area, and guide them to all these sites."14 The project in question adds to existing tourism infrastructure so as to create a cross-border network of tourism sites that could serve local interests in a way that overlaps with EU funding priorities. A park official on the Hungarian side of the project team explains their common aims in the following terms: "We would like people to come to stay in this region... The main task of the project is to have tourists stay one night or more. We have built new accommodations in Slovenia (...) near the border, we have purchased bikes, and each partner has to build a park." 15

\section{CONCLUSION}

The continued adaptations of closed border regimes in the course of Europe's lockdown during the COVID-19 crisis point to a "debordered Europe", which manifests itself in everyday practices that cannot be easily dismantled. For example, the Slovenian media highlighted problems with lorries and other vehicles stranded at Slovenian borders as transit routes were cut off at different border checkpoints, necessitating the coordination of numerous countries to aid those stuck in continuing to their destination - even in the form of humanitarian convoys (A.V. 2020). Numerous persons attempted to make their way back to their home country despite closed borders with the aid of state interventions (DAUGUL 2020). Furthermore, "exceptions" were quickly devised for residents living along borders - not only for those along the Hungarian-Slovenian border (HANžıč 2020) but also the Slovenian-Austrian one (AmBrož 2020).

One cannot deny the historical project of EU integration as a set of debordering initiatives that encourage new relationships among neighboring nations, which result in exceptions to closed border regimes, even during a crisis. However, the notion of a "debordered Europe" has its limits, not only because it is associated with a more fundamental and structural understanding of borders, but also because it operates as a narrow, often normative analytical concept. In the context of integration discourse, debordering is understood primarily as a uni-directional progression towards ever-greater unity, leaving no room for practices and dynamics that do not fit into a binary structure.

The ethnographic discussion of the interviews expands on the often narrow understanding of debordering by situating projects as debordering initiatives within actors' referential frameworks of positionality and relationships. This also entails taking into consideration that debordering and rebordering can operate as two sides of the same coin (YNDIGEGN 2011), as two possible forms of bordering practice. While narrated experiences naturally address relationships with cross-border partners and communities, they also reflect the network of significant relationships - and social boundaries - into which debordering initiatives become embedded - including the state center and fellow border actors as well as cross-border partners. Furthermore, as the interview excerpts demonstrate, the introduction of debordering encourages a range of crossborder practices: developing partnerships across borders, finding solutions to common

14 Interview with a municipal official (March 2019).

15 Interview with a park official (March 2019). 
problems, and developing joint approaches to achieve common goals. At the same time, these same initiatives also encourage rebordering, which can take numerous forms: heightened boundaries resulting from an increased awareness of differences among project stakeholders; the introduction of new issues that intensify or even problematize established relationships; or the creation of new boundaries that result from divergent priorities, visions, and approaches. Rebordering processes do not always have a crossborder dimension but may result from the significant relationships in terms of which actors interpret life on the borderland. These can also include the relationships with fellow actors on one side of the border, as competition and collaboration for crossborder projects can reveal divergent views concerning local priorities, local development visions, and EU-based border agendas. These relationships demonstrate how crossborder projects - and their impacts - are multiply defined, both socially and spatially.

Thus, exploring how border actors embed their project experiences into the context of their remaining border practices and tracing their referential framework can serve as a guideline for adequately contextualizing debordering as one of many border practices in an interconnected Europe. This may help examine cross-border cooperation as an ongoing, multi-directional process, whose impact on border life is still taking shape.

\section{REFERENCES CITED}

ABÉLÈs, Marc

2000 Virtual Europe. In BelLier, Irène - Wilson, Thomas (eds.) An Anthropology of the European Union: Building, Imagining and Experiencing the New Europe, 31-52. Oxford: Berg.

2004 Identity and Borders: An Anthropological Approach to EU Institutions. Online Working Paper, 4. The Center for 21st Century Studies, University of Wisconsin-Milwaukee. https://www4.uwm.edu/c21/pdfs/workingpapers/ abeles.pdf (accessed April 10, 2020.)

AмBRož, Nina.

2020 Slovensko-avstrijska meja: Nujno je potrdilo delodajalca ali zdravnika [The Slovenian-Austrian Border: Employer's of Doctor's Confirmation Necessary]. Večer 23 March. https://www.vecer.com/slovensko-avstrijska-meja-nujno-jepotrdilo-delodajalca-ali-zdravnika-10146561 (accessed May 29, 2020.)

A.V. - STA

2020 Preko Slovenije krenil prvi humanitarni konvoj potnikov in tovornih vozil [First Humanitarian Convoy of Motorists and Cargo Vehicles Across Slovenia.] Delo March 14. https://www.delo.si/novice/slovenija/preko-slovenijo-krenilprvi-humanitarni-konvoj-potnikov-in-tovornih-vozil-288912.html (accessed May 29, 2020.)

BAJUK SENČAR, Tatiana

2014 European Integration as Cultural Practice: The First Generation of Slovene Eurocrats. Ljubljana: ZRC SAZU.

2019 Cross-Border Cooperation and the Europeanization of the Slovenian Hungarian Border Region. Traditiones 48(1):213-231. https://doi.org/10.3986/ Traditio2019480109 
Bitsch, Marie-Thérèse.

2003 Le Fait Régional et la Construction Européenne [The Reality of Regionalism and the Construction of Europe]. Brussels: Bruylant.

Borneman, John - Fowler, Nick

1997 Europeanization. Annual Review of Anthropology 26(1):487-514.

CASSIDY, Kathryn - YuvAL-DAVIS, Nira - WeMYSS, Georgie

2018 Debordering and Everyday (Re)bordering in and of Dover: Post-Borderland Borderscapes. Political Geography 66:171-179.

COUNCIL OF EuROPE

1980 European Outline Convention on Transfrontier Co-operation Between Territorial Communities or Authorities. https://www.coe.int/en/web/ conventions/full-list/-/conventions/treaty/106 (accessed May 2, 2020)

Daugul, Larisa

2020 Zgodbe Slovencev, ki niso vedeli, kako težko se bo vrniti domov. MMC RTV. March 25. https://www.rtvslo.si/slovenija/zgodbe-slovencev-ki-niso-vedelikako-tezko-se-bo-vrniti-domov/518276 (accessed May 29, 2020)

Del Sarto, RafFaella A.

2010 Borderlands: The Middle East and North Africa as the EU's Southern Buffer Zone. In BecheV, Dimitar - Nicolaidis, Kalypso (eds.) Mediterranean Frontiers: Borders, Conflicts and Memory in a Transnational World, 149-167. London: I.B Tauris.

DEŠNIK, Stanka - DoMANJKO, Gregor

2011 Goričko-Raab-Örség: Developing with Nature in a Trilateral Park. In Pezold, Tomasz - VAsiliJević, Maja (eds.) Crossing Borders for Nature: European Examples of Transboundary Conservation. Gland, Switzerland and Belgrade, Serbia: IUCN Programme Office for South-Eastern Europe, 39-41.

Donnan, Hastings - Haller, Dieter

2000 Liminal no More. Ethnologia Europaea 30(2):7-22. DOI: https://doi. org/10.16995/ee.902

FoLLIS, Karen

2012 Building Fortress Europe: The Polish-Ukrainian Frontier. Philadelphia: University of Pennsylania Press.

GIRTLER, Roland

1992 Schmuggler - von Grenzen und ihren Uberwindern [Smugglers - from borders

GreEN, Sarah and their conquerors.] Linz: Veritas.

2013 Borders and the Relocation of Europe. Annual Review of Anthropology 42:345-361. https://doi.org/10.1146/annurev-anthro-092412-155457

HANŽIČ, Mojca

2020 Madžarska zaprla mejo s Slovenijo. Prehod možen le na treh točkah [Hungary Closed the Border with Slovenia: Crossing Possible Only at Three Checkpoints.] 24ur.com https://www.24ur.com/novice/svet/madzarska-zaprlamejo-s-slovenijo-prehod-mozen-le-na-treh-tockah.html (accessed April 20, 2020). 
Holmes, Doug

2000 Integral Europe: Fast-Capitalism, Multiculturalism, Neofascism. PrincetonOxford: Princeton University Press.

van Houtum, Henk - Kramsch, Olivier - Zierhofer, Wolfgang (eds.)

2005 B/Ordering space. Aldershot - Burlington: Ashgate.

van Houtum, Henk - Laine, Jussi - Scott, James

2016 EUBORDERSCAPES: Potentials and Challenges of Evolving Border Concepts. In Sсотт, James W. (ed.) Cross-Border Review: European Crisis and its Consequences for Borders and Cooperation, 135-152. Budapest: European Institute of Cross-Border Studies.

Ispán, Ágota Lídia

2019 Transformation of a Strictly Controlled Border Area into a Tourist Destination: Making Heritage in Communist Hungary. Traditiones 48(1):77-100. https:// doi.org/10.3986/Traditio2019480103

KAISER, Wolfram - Leucht, Brigitte - RaSMUSSEN, Morgen (eds.)

2009 The History of the European Union. Origins of a Trans- and Supranational Policy 1950-1972. Abingdon: Routledge.

Kozorog, Miha

2019 "They Feed Here and Live There": Borderwork with Wildlife in Slovenia's North-East Corner. Traditiones 48(1):191-211. http://doi.org/10.3986/ Traditio2019480108

MANDEL, Ruth

1994 "Fortress Europe" and the Foreigners Within: Germany's Turks. In GodDARD, Victoria - Llobera, Josep R. - Shore, Cris (eds.) The Anthropology of Europe: Identities and Boundaries in Conflict, 113-124. Oxford - Washington DC: Berg.

McCALL, Cathal

2012 Debordering and Rebordering the United Kingdom. In Wilson, Thomas M. Donnan, Hastings (eds.) A Companion to Border Studies, 214-229. Malden - Oxford: Wiley-Blackwell.

MCDonald, Maryon

1996 "Unity in Diversity": Some Tensions in the Construction of Europe. Social Anthropology 4:47-60.

MÉsZÁros, Csaba

2019 Flexible Boundaries at the Slovenian Raba Region: The Story of Two Infrastructure Development. Traditiones 48(1):233-250. https://doi. org/10.3986/Traditio2019480110

MinNICH, Robert Gary

2006 Some Reflections over Inter-Disciplinary Cooperation in the Study of an InterState Region: The Austro-Italian-Slovene Borderland. In ČIUBRINSKAS, Vytis - Sliužrnskas, Rimantas. Defining Region: Socio-Cultural Anthropology and Interdisciplinary Perspectives: Part 1, 19-28. Klaipeda: KU. 
Mozer, Alfred

1973 Entwicklungspolitik zu Hause [Development Policy at Home]. In ScHöNDUBE, Claus. Entwicklungsregionen in der EWG. Ursache und Ausmaß der wirtschaftlichen Benachteiligung [Developing Regions in the EEC. Causes and Extent of Economic Disadvantage], 14-25. Bonn: Osang Verlag.

Munda HirnöK, Katalin - SlaveC Gradišnik, Ingrid

2019 Meje in spomini nanje [Borders and Border Memories]. Traditiones 48(1):2755. https://doi.org/10.3986/Traditio2019480102

O'Dowd, Liam

2002 The Changing Significance of European Borders. Regional \& Federal Studies 12(4):13-36.

Pelkmans, Mathijs

2012 Chaos and Order Along the (Former) Iron Curtain. In WiLson, Thomas M. Donnan, Hastings (eds.) A Companion to Border Studies, 269-282. Malden - Oxford: Wiley-Blackwell.

Popescu, Gabriel

2008 The Conflicting Logics of Cross-border Territorialization: Geopolitics of Euroregions in Eastern Europe. Political Geography 27:418-438. https://doi. org/10.1016/j.polgeo.2008.03.002

Reitel, Birte - Wassenberg, Bernard - Peyrony, Jean - Rubio, Jean

2015 Territorial Cooperation in Europe: A Historical Perspective. Luxembourg: Publications Office of the European Union.

RuMFORD, Chris

2006 Theorizing Borders. European Journal of Social Theory 9(2):155-169. https:// doi.org/10.1177/1368431006063330

SANDFORD, Alasdair

2020 Coronavirus: Half of Humanity now on Lockdown as 90 Countries Call for Confinement. Euronews. https://www.euronews.com/2020/04/02/coronavirusin-europe-spain-s-death-toll-hits-10-000-after-record-950-new-deaths-in-24hou (accessed May 15, 2020)

SAYAD, Abdelmalek

2004 The Suffering of the Immigrant. Cambridge - Malden: Polity Press.

ScotT, James W.

2009 Bordering and Ordering the European Neighbourhood: a Critical Perspective on EU Territoriality and Geopolitics. TRAMES: A Journal of the Humanities \& Social Sciences 13(3):232-247.

2012 European Politics of Borders, Border Symbolism and Cross-Border Cooperation. In WiLson, Thomas M. - Donnan, Hastings (eds.) A Companion to Border Studies, 83-99. Malden - Oxford: Wiley-Blackwell.

SCHUMAN, Robert

1950 The Schuman Declaration. https://europa.eu/european-union/about-eu/ symbols/europe-day/schuman-declaration_en (accessed May 12, 2020)

SHORE, Cris

2000 Building Europe: The Cultural Politics of European Integration. London: Routledge. 
Simonič, Peter

2019 Social and Spatial Adjustments in Domanjševci. Traditiones 48(1):137-165. https://doi.org/10.3986/Traditio2019480106

SLuŽba Vlade RS Za RAZVOJ IN EVROPSKO KOHEZIJSKO POLITIKO

2015 Operativni program Čezmejno sodelovanje Slovenija - Madžarska 20072013: Zbornik sofinanciranih projektov [Operational Programme: Crossborder Cooperation Slovenia - Hungary 2007-2013.] http://www.si-hu. eu/download/Zbornik-sofinanciranihprojektov-OP-SI-HU-2007-2013.pdf (accessed January 20, 2020)

SoHn, Christophe

2014 Modelling Cross-Border Integration: The Role of Borders as a Resource. Geopolitics 19(3):587-608. https://doi.org/10.1080/14650045.2014.913029

WASSENBERG, Bernard

2007 Vers une eurorégion? La coopération transfrontalière franco-germano-suisse dans l'espace du Rhin supérieur de 1975 à 2000 [Towards a Euroregion? Franco-German-Swiss cross-border cooperation in the Upper Rhine area from 1975 to 2000.] Brussels: Peter Lang.

WiLSON, Thomas M.

2012 The Europe of Regions and Borderlands. In Kockel, Ullrich - CRAITH, Máiréad Nic - Frykman, Jonas (eds.) A Companion of the Anthropology of Europe, 163-180. Chichester - Malden: Wiley-Blackwell.

YNDIGEGN, Carsten

2011 Between Debordering and Rebordering Europe: Cross-border Cooperation in the Øresund Region or the Danish-Swedish Border Region. Eurasia Border Review 2(1):47-59.

Tatiana Bajuk Senčar is a research fellow at the ZRC SAZU Institute of Slovenian Ethnology and assistant professor for cultural and social anthropology at New University as a member of the Faculty of Slovenian and International Studies. In recent years, she has examined europeanization and EU integration processes as they manifest themselves through bordering practices, mobility and multi-locality as well as (transnational) professional identity formations. The last of these is the subject of her monograph entitled European Integration as Cultural Practice: The First Generation of Slovene Eurocrats (2014). E-mail: tatiana.bajuk@zrc-sazu.si 